\title{
Perspektivy výzkumu v didaktice cizích jazyků
}

\author{
Research perspectives in foreign language didactics \\ Michaela Píšová, Světlana Hanušová
}

\begin{abstract}
Abstrakt: Po období ,anti-didaktiky“ v 90. letech minulého století zaznamenáváme v posledním desetiletí obnovení zájmu o oborově didaktické myšlení. S procesy emancipace oborových didaktik př́mo souvisí vymezení metodologie specifické pro danou disciplínu a také komplexní charakteristika výzkumného pole. Př́ispěvek mapuje aktuální zaměření a metody výzkumu v didaktice cizích jazyků (s akcentem na didaktiku anglického jazyka) v České republice.
\end{abstract}

Klíčová slova: didaktika cizích jazyků; metody výzkumu v didaktice cizích jazyků; tematické zaměření výzkumných studií; perspektivy výzkumu v didaktice cizích jazyků

\begin{abstract}
After the "anti-didactic era" in the 90s of the last century the renewal of interest in subject matter didactic thinking has been noted. Subject matter didactic and its emancipation processes are directly linked to the specification of research methods and with complex characteristics of research field. The paper maps current focus and research methods in foreign language didactics (with special attention to English language didactics) in the Czech Republic.
\end{abstract}

Keywords: foreign language didactics; research methods in foreign language didactics; research focus; perspectives of research in foreign language didactics

\section{1 Úvodem}

Procesy emancipace oborových didaktik prímo souvisí s vymezením metodologie specifické pro danou disciplínu a s komplexní charakteristikou výzkumného pole. V oblasti výuky cizích jazyků a jejího výzkumu jsme v současné době svědky obrovského rozvoje. E. Hinkel (2005, s. xviii) pro ilustraci uvádí, že počet a geografický dosah asociací zabývajících se výukou angličtiny a její didaktikou je již téměř nepřehledný; např. TESOL zahrnuje více než 20 odborných skupin (Special Interest Groups) a má 90 přidružených organizací na všech obydlených kontinentech. Počet odborných akcí, konferencí, seminářŭ, sympozií, kolokvií apod., je celosvětově vyšší než 6 měsíčně (tj. každých 5 dní po celý rok). Je proto velmi obtížné sledovat a systemizovat výzkumné a metodologické trendy.

Pro didaktiku cizích jazyků je rovněž charakteristická velká vnitřní diverzifikace: pod jedním zastřšujícím termínem autonomně fungují didaktiky různých cizích jazyků (didaktiky anglického, německého, ruského, francouzského a dalších jazyků, a to včetně jazyků tzv. mrtvých či jazyků umělých). V jejich vývoji vedoucím k současnému stavu lze vysledovat různé kulturně podmíněné př́stupy k reflexi edukační reality (např. Didaktik vs. curriculum studies; např. Gundem \& Hopmann, 2004; podrobněji Píšová, 2011), kromě toho se samozřejmě i zde uplatňuje paradigmatická pluralita typická pro společenské vědy. Dále je 
pro didaktiku cizích jazyků charakteristická tenze $\mathrm{v}$ silovém poli jejích pomocných věd (Choděra 2006, s. 28-36), její různá pojetí pak vyplývají z blízkosti - či vzdálenosti - k té které z nich.

Z uvedeného je zřejmé, že snaha o charakteristiku výzkumného pole i metodologie výzkumu $\mathrm{v}$ didaktice cizích jazyků je záležitostí velmi obtížnou a komplikovanou. V tomto př́spěvku se omezíme na stručný komentár̆ $\mathrm{k}$ metodám výzkumu a pokusíme se nabídnout ilustrativní „mapu“ tematického zaměření výzkumů realizovaných v oblasti didaktiky cizích jazyků v České republice v posledním desetiletí.

\section{Metody výzkumu v didaktice cizích jazyků}

Oborové didaktiky obecně vycházejí jak z metod výzkumu v mateřských oborech, tak $\mathrm{v}$ pedagogice, a to $\mathrm{v}$ závislosti na jejich aktuálním pojetí a na jejich konkrétním cíli, na výzkumné otázce. To platí i o didaktice cizích jazykủ. Na rovině konceptualizační je pro stanovení cílů výzkumu zásadní formulace předmětu a objektu didaktiky cizích jazyků (k rozlišení předmětu a objektu vědní disciplíny Malír̆, 1971; Choděra, 2006, s. 13 aj.). S odvoláním na podrobnější diskusi (Píšová, 2011, s. 148-152) se přikláníme k názoru M. Dakowské (2003), která za dosažitelný a stabilní fenomén reálného světa, za empirickou realitu, jejíž teoretická reflexe představuje vědní základnu didaktiky cizích jazyků, považuje verbální komunikaci v daném jazyce. Takové pojetí implikuje komplexní strukturu předmětu a objektu didaktiky cizích jazyků - můžeme hovořit o systému systémů v dynamické interakci. H. Seliger a E. Shohamy (2000, s. 26-27) jej ilustrovali na př́kladu oblasti osvojování anglické výslovnosti (obrázek 1):

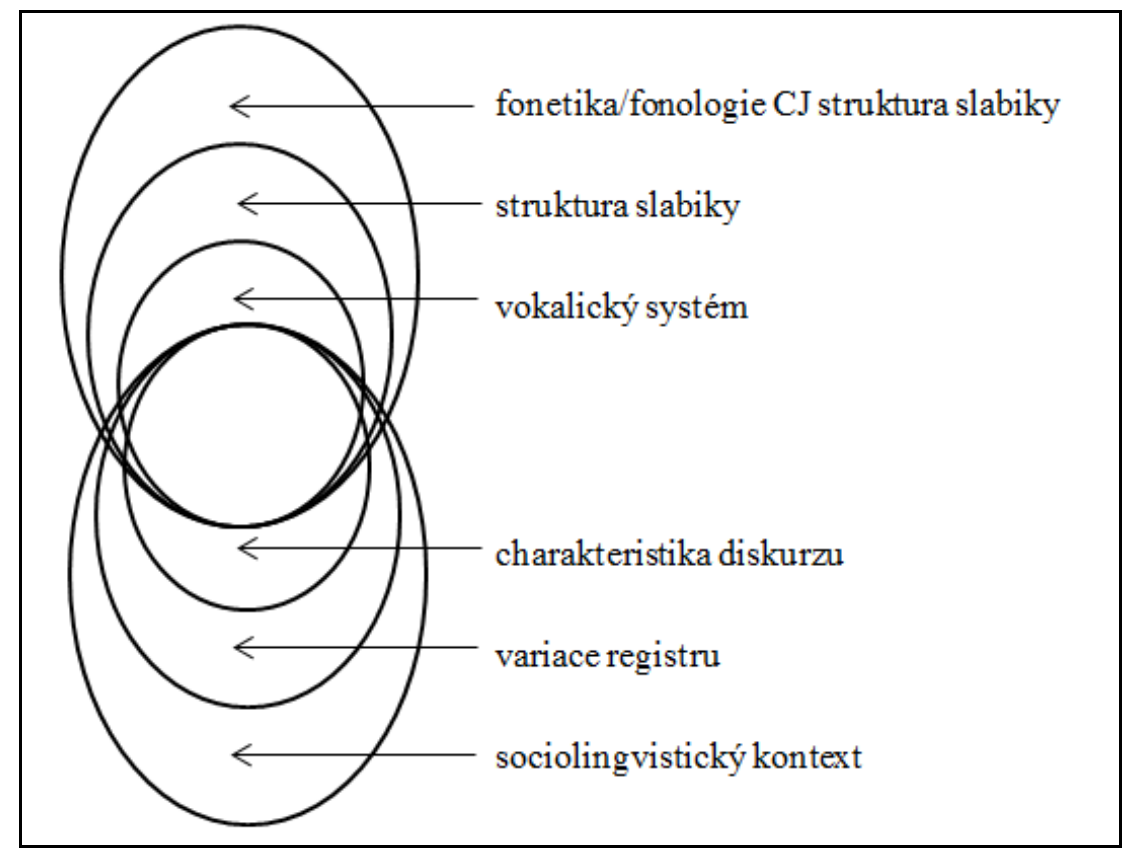

Obrázek 1. Systémový pohled na oblast osvojování anglické výslovnosti (Seliger \& Shomay, 200, s. 27).

Didaktika cizích jazyků se pak zaměřuje na intencionální osvojování tohoto komplexního fenoménu v procesech formálního vzdělávání, jejím předmětem je, řečeno slovy $F$. Malíře (1971, s. 102) tedy didaktická realita a její širší okolí. Ze systémového pojetí zrretelně 
vyplývá, že výzkum $\mathrm{v}$ dané oblasti může být koncipován holisticky/synteticky či analyticky/partikularisticky, tj. zaměřit se na celek či pouze některou z jeho částí.

Na rovině operacionalizační využívá didaktika cizích jazyků standardních metod výzkumu ve společenských vědách, na základě formulace výzkumné otázky např. metod pedagogiky, psychologie, antropologie, sociologie (Hinkel, 2005 aj.). Uplatňuje se jak kvantitativní, tak kvalitativní metodologie, v poslední době pak nabývá na významnosti využití smíšené metodologie, která umožňuje hlouběji a spolehlivěji pronikat do procesů učení se / vyučování cizího jazyka v prostředí formálního vzdělávání.

\section{Tematická „mapa“ zaměření empirického výzkumu v didaktice cizích jazyků v České republice}

Jaké výzkumné otázky klade současný výzkum v didaktice cizích jazyků u nás? Na které oblasti empirické reality je zaměřen? V jakém rozsahu postihuje komplexně vymezený předmět této vědní disciplíny? Pokusili jsme se najít odpovědi na tyto otázky prostřednictvím analýzy dostupných výzkumných studií provedených v České republice v posledním desetiletí. Do výběru výzkumů pro analýzu byly zahrnuty studie publikované v odborných časopisech Pedagogika, Pedagogická orientace, Studia paedagogica (včetně předchozí sborníkové podoby této platformy), Orbis scholae, Lingua viva a e-Pedagogium, dále pak habilitační a disertační práce zabývající se výzkumem v didaktice cizích jazyků a obhájené na FF UK v Praze, PedF UK v Praze, PedF MU v Brně a PedF UP v Olomouci. Pro doplnění přehledu jsou uvedeny i grantové projekty realizované v rámci GA ČR.

Neaspirovali jsme na získání vyčerpávajícího přehledu zejména z toho důvodu, že velké množství drobnějších studií různé kvality je tradičně publikováno ve sbornících, z nichž některé nejsou recenzované, a tudíž lze jen obtížně soudit na jejich kvalitu. Dále jsme si vědomi toho, že i některá lingvisticky orientovaná periodika vydávaná na fakultách občas dávají prostor textům svým charakterem aplikovaně lingvistickým či didaktickým (např. Brünner Hefte zu Deutsch als Fremdsprache, vydáváno na PedF MU v Brně). Zejména na pedagogických fakultách $v$ Brně i v Praze byly také $v$ souvislosti $\mathrm{s}$ řešením výzkumných záměrů vydány monografie zabývající se didaktikou cizích jazyků. Přinášíme tedy svým způsobem spíše ilustrativní tematickou „mapu“ zaměření empirického výzkumu.

Ve výše uvedených zdrojích bylo nalezeno celkem 94 položek pro analýzu. Zastoupení výzkumu v didaktikách různých cizích jazyků přináší přehledně tabulka 1.

I přes ne zcela rovnoměrné rozložení položek a výraznou převahu výzkumných studií v didaktice anglického jazyka je potěšitelné zastoupení didaktik všech tzv. velkých jazyků.

Tabulka 1

Výzkumné studie v didaktikách různých jazyki̊

\begin{tabular}{lll}
\hline DAJ & 55 & $58,51 \%$ \\
\hline$D N J$ & 17 & $18,09 \%$ \\
$D R J$ & 6 & $6,38 \%$ \\
DFJ & 9 & $9,57 \%$ \\
obecně: DCJ & 7 & $7,45 \%$ \\
\hline
\end{tabular}

DAJ - didaktika anglického jazyka; DNJ - didaktika německého jazyka; DRJ - didaktika německého jazyka; DFJ - didaktika francouzského jazyka; DCJ - didaktika cizích jazyků 
Analýza zaznamenaných položek z hlediska tematického zaměření studií identifikovala 5 hlavních oblastí výzkumu, a to studie věnované problematice učitele cizích jazyků, procesům učení se / osvojování cizího jazyka, metodám a organizaci výuky, verbální komunikaci a skupinu do nich nezařazených tematicky rozrůzněných studií (obrázek 2). Na obrázku jsou hvězdičkami označeny habilitační práce zpracované a úspěšně obhájené v dané tematické oblasti; za pozitivum lze považovat fakt, že jsou rozloženy prakticky do všech identifikovaných oblastí.

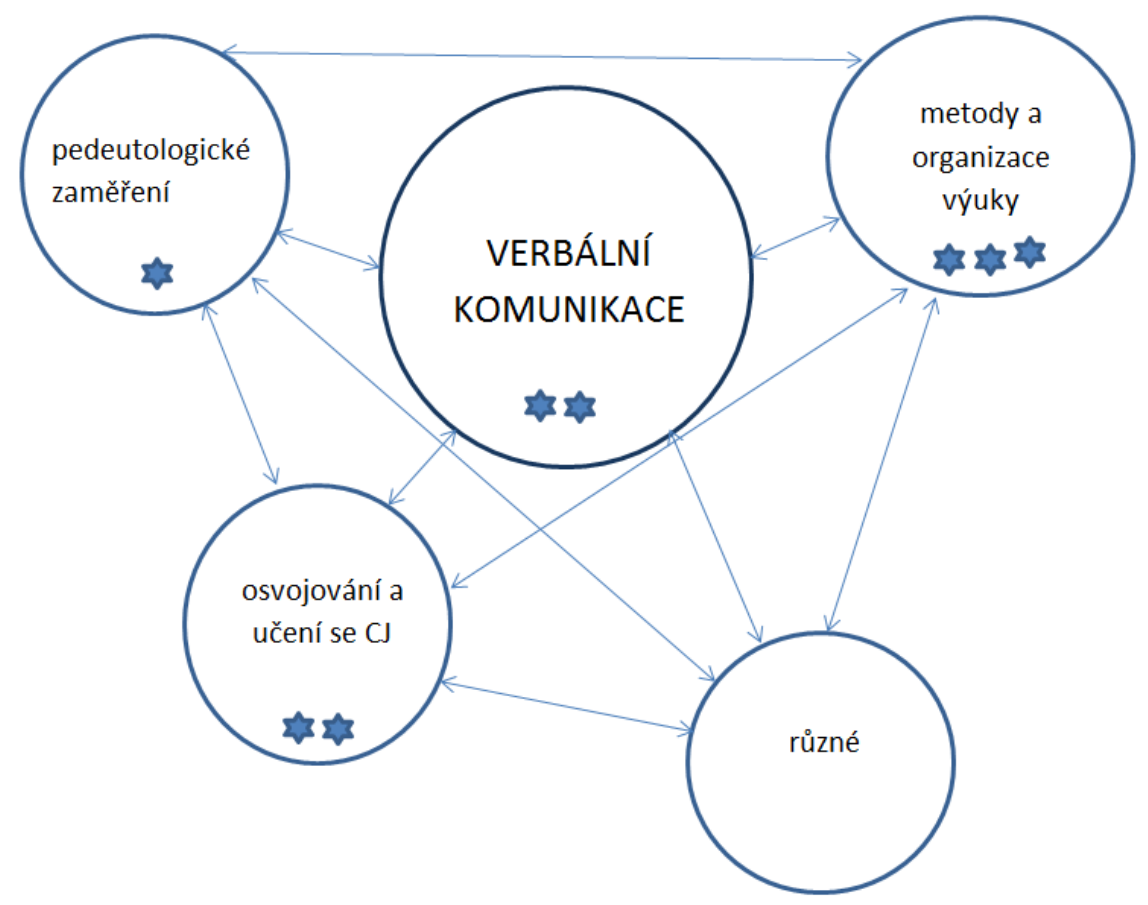

Obrázek 2. Tematická „mapa“ zaměření empirického výzkumu v didaktice cizích jazyků v České republice

Pro upřesnění dále uvádíme zastoupení různých typů položek v jednotlivých oblastech a také podoblasti, kterým byla $\mathrm{v}$ jejich rámci věnována výzkumná pozornost:

- Pedeutologická problematika zahrnovala celkem 12 položek, z toho:

○ habilitační práce 1 ,

- disertační práce ukončené 6 ( $\mathrm{z}$ toho 3 věnované e-learningu),

○ články v odborných periodikách 5 .

Doplnit je třeba v analýze nezapočítané 2 projekty GA ČR.

- Problematika osvojování a učení nemateřského jazyka je oblastí, kam spadaly:

a) vliv faktorů spojených s individuálními zvláštnostmi na proces osvojování jazyka

b) zohlednění individuálních zvláštností a potřeb žáka při projektování a realizaci

kurikula, tj. individualizace a diferenciace

c) výuka cizího jazyka u žáků se specifickými potřebami

Patř́ sem celkem 10 položek, z toho:

- habilitační práce 2 ,

○ disertační práce ukončené 3,

○ články v odborných periodikách 6 .

- Metody a organizace výuky cizich jazyki̊ jsou relativně hojně zastoupenou oblastí, pod níž patř́i: 
a) prístupy/metody a organizace výuky

b) CLIL (Content and Language Integrated Learning)

c) analýza a hodnocení učebnic

d) e-learning

e) testování / hodnocení

Nalezeno bylo celkem 17 položek, z toho:

○ habilitační práce 3,

- disertační práce ukončené 9,

○ články v odborných periodikách 8 .

Doplnit sem lze i 1 řešený projekt GA ČR.

- VERBÁLNÍ KOMUNIKACE představuje počtem položek nejbohatší oblast, v rámci které je možné vydělit podoblasti:

a) komunikační kompetence

b) interkulturní komunikační kompetence (včetně reálií a literatury ve výuce cizích jazykü)

c) jazykové prostredky

d) diskurz školní třídy

e) odborný jazyk (language for specific purposes - LSP)

f) problematika mateřského jazyka ve výuce cizího jazyka

$\mathrm{V}$ těchto podoblastech se vyskytlo celkem 46 položek, z toho:

○ habilitační práce 2 ,

- disertační práce ukončené 31 ,

○ články v odborných periodikách 15 .

Dále připojujeme 1 řešený projekt GA ČR.

- Po hlavičkou Různé se objevily celkem 4 položky, a to 4 ukončené a obhájené disertační práce. Kromě toho je třeba uvést ještě 3 získané grantové projekty GA ČR.

\section{4 „Dobré“ a ,špatné‘ zprávy neboli k perspektivám výzkumu v didaktice cizích jazyků}

Analýza tematického zaměření výzkumných studií přinesla jak některé pozitivní, tak negativní nálezy. K pozitivním patří především fakt, že výzkum v České republice v posledním desetiletí dostatečným a poměrně vyrovnaným způsobem pokrývá široké spektrum tematických oblastí didaktiky cizích jazyků, přičemž akcent je jednoznačně kladen na centrální oblast verbální komunikace. Výčet podoblastí zároveň ukazuje, že výzkum reflektuje společenskou objednávku; v dostatečné míře se objevují aktuální témata, jako např. CLIL, individualizace a diferenciace ve výuce cizích jazyků, interkulturní kompetence a podpora jejího rozvoje $\mathrm{v}$ rámci výuky cizích jazyků. Je ale zároveň třeba varovat před nebezpečím „módnosti“ některých témat, a to nejen $z$ hlediska jejich frekventovanosti ve výzkumu, ale především $\mathrm{z}$ hlediska přeceňování jejich významu ve vztahu k předmětu a objektu didaktiky cizích jazyků.

Další dobrou zprávou je nepochybně vědecký růst odborné komunity didaktiků cizích jazyků. Nejde jen o počet nově habilitovaných akademických pracovníků, tj. celkem 8 nových docentů, ale zároveň o to, že jejich odborné zaměření pokrývá všechny identifikované tematické oblasti výzkumu (viz obrázek 2 výše). Noví docenti se prritom rekrutují z didaktik různých jazyků (konkrétně 3 habilitace proběhly v didaktice anglického jazyka, 4 v didaktice 
německého jazyka a $1 \mathrm{v}$ didaktice francouzského jazyka). Přičteme-li k těmto faktům i dva $\mathrm{v}$ posledních letech akreditované programy doktorského studia v oboru, můžeme konstatovat, že didaktika cizích jazyků obstojí z pohledu současného trendu, o kterém T. Janík a I. Stuchlíková (2010) hovoří jako o oborových didaktikách na vzestupu.

Nelze ale přitom přehlížet ,špatné“ zprávy, které z analýzy vyplývají. Ukazuje se, že přetrvává vysoká diverzifikace „uvnitř“ didaktiky cizích jazyků, což se odráží v atomizaci emancipačního úsilí. Co didaktice cizích jazyků chybí? Jsou to především společné publikační platformy a výzkumné projekty, které by podpořily odbornou komunikaci vedoucí v rámci didaktiky cizích jazyků k teoretické konceptualizaci. Poukázat je možno i na nedostatečnou transdidaktickou komunikaci, tj. komunikaci s didaktikami jiných - nejen společenskovědních - oborů. Ta je nezbytná jak pro řešení otázek teoretických, ale i pro rovinu aplikační (např. v př́ipravném i dalším vzdělávání učitelů).

Vnímáme-li tato zjištění jako informativní pro potřeby budoucího výzkumu v didaktice cizích jazyků, je nutno také volat po tom, aby zaujal vůdčí roli v zavádění nových trendů, či alespoň roli kritického př́itele při jejich implementaci; až dosud se bohužel spíše jedná o ex-post výzkumy inovací zaváděných vzdělávací politikou. Zcela na závěr se pak sluší připomenout, že tato stat' byla věnována pouze výzkumu empirickému. Teoretický výzkum v didaktice cizích jazyků směřující k rozvoji metadidaktiky pojímané jako „svědomí“ oboru (Choděra, 2006, s. 36- 38) představuje samostatnou kapitolu, které je nutno věnovat samostatnou diskusi.

\section{Literatura}

Dakowska, E. (2003). Current controversies in foreign language didactics. Warszawa: Wydawnictwa Uniwersytetu Warszawskiego.

Gundem, B. B., \& Hopmann, S. (Eds.). (2002). Didaktik and/or curriculum. An international dialogue. New York: Peter Lang.

Hinkel, E. (Ed.). (2005). Handbook of research in second language teaching and learning. Mahwah, New Jersey/London: Lawrence Erlbaum Associates, Inc.

Janík, T. \& Stuchlíková, I. (2010). Oborové didaktiky na vzestupu: přehled aktuálních vývojových tendencí. Scientia in educatione, 1(1), 5-32.

Choděra, R. (2006). Didaktika cizich jazykù. Úvod do vědního oboru. Praha: Academia.

Malíŕ, F. (1971). Didaktiky cizich jazykư jako vědni obory. K problematice jejich předmětu. Praha: Academia.

Píšová, M. (2011). Didaktika cizích jazyků: otázky identity. Pedagogická orientace, 21(2), 145-155.

Seliger, H. W., \& Shohamy, E. (2000, 5th impression). Second language research methods. Oxford: Oxford University Press.

\section{Kontakt}

Doc. PhDr. Michaela Píšová, M.A., Ph.D.

Masarykova univerzita

Pedagogická fakulta, Institut výzkumu školního vzdělávání a Katedra anglického jazyka a literatury

Poříčí 31, 60300 Brno

e-mail:pisova@ped.muni.cz

Doc. Mgr. Světlana Hanušová, Ph.D.

Masarykova univerzita

Katedra anglického jazyka a literatury

Poříčí 31, 60300 Brno

e-mail: hanusova@ped.muni.cz 


\section{Bibliografické údaje}

Píšová, M., \& Hanušová, S. (2011). Perspektivy výzkumu v didaktice cizích jazyků. In T. Janík, P. Knecht, \& S. Šebestová (Eds.), Smišený design v pedagogickém výzkumu: Sborník přispěvkũ z 19. výročni konference České asociace pedagogického výzkumu (s. 398-404). Brno: Masarykova univerzita.

Dostupné z: http://www.ped.muni.cz/capv2011/sbornikprispevku/pisovahanusova.pdf doi: 10.5817/PdF.P210-CAPV-2012-47 